\title{
Kesadaran Petani Lokal Memanfaatkan Sirih Hutan (Piper betle L.) sebagai Pestisida Nabati dalam Pengendalian Hama Tanaman Ubi Jalar (Ipomea batatas L.) Kabupaten Manokwari Papua Barat
}

\author{
Michel Koibur $^{1 *}$, Mika Marandof ${ }^{1}$, Elwin $^{1}$ \\ ${ }^{1}$ Program Studi Penyuluhan Pertanian Berkelanjutan, Politeknik Pembangunan Pertanian \\ Manokwari \\ Email: yorgenmich72@gmail.com
}

\begin{abstract}
Abstrak
Salah satu upaya penerapan pertanian organik yaitu dengan menggunakan pestisida nabati. Pupuk organik cair sirih hutan (Piper betle L.) merupakan salah satu pupuk nabati yang dikaji dalam proses perlindungan tanaman ubi jalar (Ipomoea batatas L.), terhadap hama ubi jalar. Ubi jalar merupakan tanaman pangan lokal papua yang dikonsumsi sebagai penganti nasi, sehingga perlu untuk dilakukan perlindungan. Penelitian ini bertujuan menganalisis pemanfaatan sirih hutan, (Piper betle L.) sebagai bahan ekstrak pestisida nabati organik cair pada tanaman ubi jalar. Penelitian ini dilaksanakan di Kampung Petrus Kafiar, Distrik Manokwari Barat. Metode penelitian menggunakan rancangan acak kelompok dengan perlakuan, P0, E1 (kontrol, tanpa perlakuan), P1, E2 (ekstrak sirih: tembakau, 1:1), P2, E3 (ekstrak sirih : tembakau, 2:1), P3. E4 (Ekstrak sirih : tembakau, 3:1), yang masing-masing perlakuan dilakukan ulangan semprotan 3 kali sehari pada tanaman ubi jalar. Untuk mengetahui intensitas serangan hama dilakukan analisis terhadap jumlah daun ubi jalar yang rusak. Hasil penelitian menunjukkan bahwa pestisida ekstrak sirih hutan dan tembakau berpengaruh signifikan terhadap intensitas serangan hama baik pada 17 HST, 24 HST, 31 HST, 38 HST, 45 HST, 52 HST dan 59 HST. Hasil terbaik pada perbandingan ekstrak sirih hutan dan tembakau 1: 1 yang ditunjukkan dengan jumlah daun ubi jalar yang rusak paling sedikit.
\end{abstract}

Kata kunci: Hama, Pestisida nabati, Sirih hutan, Ubi jalar

\section{Abstract}

One of the efforts to implement organic farming is by using vegetable pesticides. Forest betel liquid organic fertilizer (Piper betle L) is one of the vegetable fertilizers studied in the process of protecting sweet potato plants (Ipomoea batatas L), against sweet potato pests. Sweet potato is a local food plant in Papua which is consumed as a substitute for rice, so it is necessary to protect it. This study aims to analyze the use of forest betel (piper betle L) as a liquid organic vegetable pesticide extract in sweet potato plants. This research was conducted in Petrus Kafiar Village, Manokwari Bara District. The research method used a randomized block design with treatments, P0, E1 (control, no treatment), P1, E2 (betel extract: tobacco, 1:1), P2, E3 (betel extract: tobacco, 2:1), P3. E4 (Betel extract: tobacco, 3:1), each treatment was sprayed 3 times a day on sweet potato plants. To determine the intensity of pest attacks, an analysis of the number of damaged sweet potato leaves was carried out. The results showed that forest betel extract pesticides and tobacco had a significant effect on the intensity of pest attacks at 17 DAP, 24 DAP, 31 DAP, 38 DAP, 45 DAP, 52 DAP and $59 D A P$. The best results were in the ratio of forest betel extract and tobacco 1:1 which was indicated by the least number of damaged sweet potato leaves.

Keyword: Forest betel, Pests, Sweet potato, Vegetable pesticides 
Prosiding Seminar Nasional Pembangunan dan Pendidikan Vokasi Pertanian

Politeknik Pembangunan Pertanian Manokwari, 31 Juli 2021

e ISSN : 2774-1982

DOI : https://doi.org/10.47687/snppvp.v2i1.195

\section{PENDAHULUAN}

Pertanian organik dan ramah lingkungan merupakan konsep pertanian yang saat ini banyak ditawarkan. Salah satu cara penerapan pertanian organik yaitu dengan menggunakan pestisida nabati organik cair sirih hutan, (Piper betle L.) dalam proses perlindungan tanaman ubi jalar (Ipomoea batatas L.). Dalam kegiatan penelitian ini, perlu memperkenalkan pemanfaatan sirih hutan sebagai pestisida nabati cair di kalangan masyarakat petani lokal, di kampung petrus kafiar. Jenis pestisida nabati organik berkaitan erat dengan perannya dalam mengendalikan OPT (organisme pengganggu tanaman) sebagai bagian dari pengendalian hama terpadu (Maghfirillah et al., 2020). Contoh nya, beberapa pestisida yang mulai dikenal luas adalah mikroorganisme lokal (MOL) (Elwin dan Mual, 2020), insektisida nabati, nemasida nabati, fungisida (Saputra et al., 2018), bakterisida, moluskisida dan leishmanisida nabati (Tahyudin et al., 2020).

Selain itu sirih merupakan tanaman menjalar yang merambat pada batang pohon di sekelilingnya dengan daunnya yang memiliki bentuk pipih seperti gambar hati, tangkainya agak panjang, tepi daun rata, ujung daun meruncing, pangkal daun berlekuk, tulang daun menyirip, dan daging daun yang tipis. Permukaan daunnya berwarna hijau dan licin, sedangkan batang pohonnya berwarna hijau tembelek atau hijau agak kecoklatan dan permukaan kulitnya kasarserta berkerut-kerut. Sirih hidup subur dengan ditanam di atas tanah gembur yang tidak terlalu lembab dan memerlukan cuaca tropika dengan air yang mencukupi. Sirih merupakan tumbuhan obat yang sangat besar manfaatnya. Dalam farmakologi Cina, sirih dikenal sebagai tanaman yang memiliki sifat hangat dan pedas, tanaman sirih hutan sangat dapat berpotensi digunakan sebagai bahan dasar pembuatan insektisida atau pestisida nabati cair yang ramah lingkungan karena mengandung senyawa kimia berupa fenol dan khavikol. Senyawa tersebut mampu menghambat pertumbuhan larva serangga maupun serangga dewasa, menurunkan intensitas penyakit pertanaman, penurunan pertumbuhan bakteri, serta sebagai biofungisida untuk menghambat pertumbuhan jamur pada tanaman. Kampung Petrus Kafiar adalah salah satu kampung yang termasuk dalam wilayah pemerintahan administratif Distrik Manokwari Barat, Kabupaten Manokwari, Provinsi Papua Barat. Dari Kampung Petrus Kafiar ke pusat distrik jarak yang dapat ditempuh menggunakan kendaraan roda 2 ataupun roda 4 adalah $\pm 5 \mathrm{~km}$, dan juga ke pusat kota berjarak $\pm 5 \mathrm{~km}$, yang dapat ditempuh dengan mengunakan kendaraan roda 2 ataupun kendaraan roda 4. Keadaan sektor pertanian di Kampung Petrus Kafiar memiliki prospek yang cukup baik, hal ini didukung oleh luas lahan yang 
Prosiding Seminar Nasional Pembangunan dan Pendidikan Vokasi Pertanian

Politeknik Pembangunan Pertanian Manokwari, 31 Juli 2021

e ISSN : 2774-1982

DOI : https://doi.org/10.47687/snppvp.v2i1.195

memungkinkan untuk berusaha tani, sektor pertanian di Kampung Petrus Kafiar meliputi sektor pertanian jangka panjang maupun jangka pendek tetapi komoditi utama yang dibudidayakan adalah komoditi tanaman hortikultura dan tanaman pangan ubi-ubian, yang termasuk dalam kajian penelitian yaitu ubi jalar (Ipomea batatas L.).

Tanaman ubi jalar (Ipomea batatas L.) merupakan tanaman pangan lokal yang dikonsumsi sebagai penganti nasi, sehingga perlu untuk dilakukan perlindungan ubi jalar, terhadap hama tanaman ubi jalar guna peningkatan hasil ubi jalar. Di Kampung Petrus Kafiar, banyak petani yang menanam ubi jalar, namun banyak pula yang tidak mengenal dan tidak menggunakan pestisida nabati dari tanaman sirih hutan dan bahan tambahannya tembakau. Adapun tujuan penelitian ini yaitu menganalisis pemanfaatan sirih hutan, (Piper betle L.) sebagai bahan ekstrak pestisida nabati organik cair pada tanaman ubi jalar.

\section{METODE}

Pelaksanaan kajian dilakukan mulai bulan Maret sampai Juni 2020, Di Kampung Petrus Kafiar, Distrik Manokwari Barat, Kabupaten Manokwari, Provinsi Papua Barat. Alat dan bahan kajian penelitian yang digunakan yaitu penumbuk (cobek), parang, timbah literan, ember, tapisan, handsprayer daun sirih hutan, tembakau shag, air, gula pasir, EM4.

Penelitian menggunakan metode Rancangan Acak Kelompok, dengan perlakuan E1 (kontrol, tanpa perlakuan), E2 (Ekstrak sirih hutan : tembakau shag 1:1), E3 (Ekstrak Sirih hutan : tembakau shag 2:1), E4 (Ekstrak Sirih hutan :Tembakau shag (3:1). Masingmasing perlakuan diulang 2 kali sehari., dengan jarak 3 hari, Persiapan Lahan diukur dan dibagi menjadi 12 (dua belas) petakan bedengan, dengan luas masing - masing $120 \mathrm{~cm} \mathrm{x}$ $120 \mathrm{~cm}$, dengan jarak lubang tanam $70 \mathrm{~cm}$ x $70 \mathrm{~cm}$, setiap lubang tanam diberikan pupuk kompos, dan (5) lima stek bibit ubi jalar perlubang tanam,setelah itu disiram dengan cairan pestisida nabati sirih hutan. Pemupukan dasar dilakukan sebelum stek ubi jalar ditanaman, Pengedalian hama menggunakan pestisida nabati ekstrak sirih hutan dan tembakau shag, sesuai perlakuan yang disemprot setiap (3) tiga hari sekali setelah penanman, dengan konsentrasi pengamatan Pembuatan ekstrak daun sirih (ES) dilakukan dengan memblender atau menumbuk 1 (satu) kg, daun sirih hutan dan di campur 1 ltr air, 1 sendok teh gula pasir, dan 1 tutup botol cairan fomula M4, lalu peram semalam dan disaring (sebagai larutan stok pestisida). Untuk mendapatkan konsentrasi 50\% maka $500 \mathrm{ml}$ ekstrak yang sudah disaring (larutan stok), dilarutkan dalam $1000 \mathrm{ml}$ air. Begitupun untuk ekstrak tembakau shag (ET). 250 gr, tembakau shag diblender atau dicampur dalam $1000 \mathrm{ml}$ air 
Prosiding Seminar Nasional Pembangunan dan Pendidikan Vokasi Pertanian

Politeknik Pembangunan Pertanian Manokwari, 31 Juli 2021

e ISSN : 2774-1982

DOI : https://doi.org/10.47687/snppvp.v2i1.195

kemudian peram semalam, dan disaring (sebagai larutan stok pestisida nabati sirih hutah). selanjtnya diencerkan dengan menambahkan 1 liter air dalam $500 \mathrm{ml}$ larutan stok pestisida.

Untuk mendapatkan biorasional 1:1, 2;1. 3;1. Maka dilakukan pencampuran ES dan ET yang sudah diencerkan dengan volume sesuai rasio perlakuan E1 (tanpa ekstrak); E2 $(1: 1=500 \mathrm{ml} \mathrm{ES} \mathrm{+500} \mathrm{ml} \mathrm{ET}) ; \mathrm{E} 3(2: 1=750 \mathrm{ml} \mathrm{ES}+250 \mathrm{ml} \mathrm{ET}) ; \mathrm{E} 4(3: 1=500 \mathrm{ml}$ $\mathrm{ES}+250 \mathrm{ml} \mathrm{ET}$ ). Pengendalian hama yang dilakukan pada proses pertumbuhan tanaman sampai mencapai tingkat kesuburan 59 hari pemgamatan. Dalam penelitian diambil sampel dari setiap petakan, Parameter pengamatan yaitu; (1) Intensitas kerusakan daun akibat serangan hama, pada tanaman ubi jalar, kajian dilakukan di Kampung Petrus Kafiar. Langkah pembuatan dan aplikasi sebagai berikut:

- Tembakau shag $250 \mathrm{mg}$ direndam dalam 1 liter air bersih.

- Daun sirih hutan $1 \mathrm{~kg}$ ditumbuk dan direndam dalam 1 liter air bersih.

- Kedua bahan diperam dalam masing - masing ember, atau wadah yang berpenutup sehingga fermentasi berlangsung sempurna dalam waktu 20-24 jam.

- Fermentasi pestisida dicek tiga kali dalam 24 jam untuk melihat perubahan warna dan aroma pada sirih hutan dan tembakau shag.

- Masing - masing pestisida cair diperas dan disaring ke jeringgen, biang ekstrak pestisida sudah siap dipakai.

- Aplikasi campurkan $1 / 2$ liter ekstrak tembakau, dan $1 / 2$ ekstrak daun sirih hutan ke dalam lima (5) liter air pada handsprayer dan semprotkan ketanaman ubi jalar yang terserang hama, dengan menggunakan pelindung mulut, mata, hidung dan sarung tangan. Penyemprotan efektif tiga (3) kali sehari pada musim hujan untuk mengusir belalang, semut, ulat, dan serangga-serangga kecil lainnya.

\section{HASIL DAN PEMBAHASAN}

Kajian materi penyuluhan yang dilakukan pada masyarakat lokal di Balai kampung yang berada di Kampung Petrus Kafiar, Distrik Manokwari Barat, Kabupaten Manokwari, Provinsi Papua Barat. Frekuensi serangan hama pada beberapa perlakuan ekstrak pestisida nabati sirih hutan pada dua belas bedengan tanaman batatas yang diamati terhadap serangan hama yang tampil serta merusak tanaman, fokus pengamatan terbesar pada daun tanaman.

Pemanfaatan sirih hutan untuk pengendalian hama pada tanaman ubi jalar (Ipomea batatas L.) dilakukan dengan melakukan kajian penelitian terelebih dahulu untuk mengetahui perlakuan atau resep (ekstrak) terbaik. Pengukuran serangan hama terhadap 
Prosiding Seminar Nasional Pembangunan dan Pendidikan Vokasi Pertanian

Politeknik Pembangunan Pertanian Manokwari, 31 Juli 2021

e ISSN : 2774-1982

DOI : https://doi.org/10.47687/snppvp.v2i1.195

daun tanaman ubi jalar dilakukan pengamatan mulai umur 17 Hari Setelah Tanam (17 HST) dengan hasil ditampilkan pada Gambar 1.

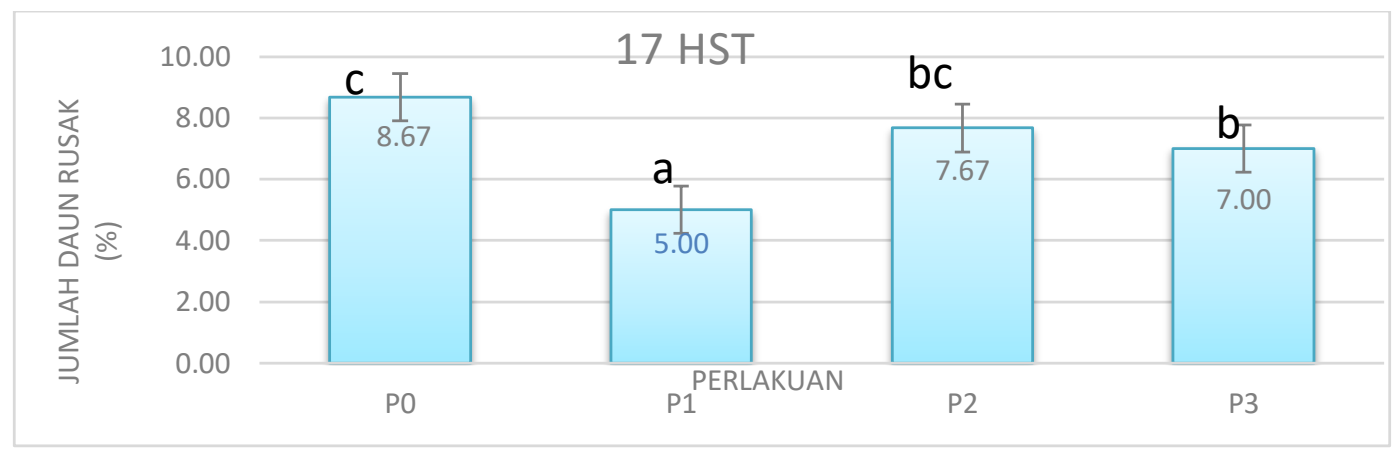

Gambar 1. Jumlah Daun Rusak pada 17 HST

Gambar 1. memperlihatkan bahwa perlakuan P0 (ekstrak 1, kontrol tanpa perlakuan) memberikan respon daun rusak dengan rata-rata 8,67\%, perlakuan P1 (ekstrak 2, ekstrak sirih hutan: tembakau 1:1) dengan rata-rata 5\%, perlakuan $\mathrm{P} 2$ dengan rata-rata 7,67\%, dan perlakuan P3 dengan rata-rata 7\%. Secara deskriptif dapat dilihat bahwa perlakuan P1 memiiki rata-rata daun rusak terserang hama lebih kecil dibandingkan perlakuan P2, P3 dan perlakuan kontrol. Hasil analisis Anova menunjukan bahwa nilai signifikasi atau $\mathrm{P}$-value lebih kecil dari pada $0,05(\mathrm{P}<0,05)$ sehingga berarti bahwa perlakuan berbeda nyata atau memberikan pengaruh yang signifikan. Artinya perlakuan memberikan respon yang berbeda terhadap serangan hama pada daun ubi jalar.

Gambar 2 memperlihatkan persentase serangan hama hari ke 24 hari setelah tanam. Gambar 2 juga memperlihatkan bahwa perlakuan P0 (ekstrak 2, kontrol tanpa perlakuan) memberikan respon daun rusak dengan rata-rata $(9,00 \%)$, perlakuan P1 (ekstrak 2, ekstrak sirih hutan: tembakau 1:1) dengan rata-rata (5\%,) perlakuan P2 dengan rata-rata (7,67\%), dan perlakuan P3 (ekstrak 3 sirih hutan : tembakau) dengan rata-rata (7 \%). Secara deskriptif dapat dilihat bahwa perlakuan P1 memiiki rata-rata daun rusak terserang hama lebih kecil dibandingkan perlakuan P2, P3 dan perlakuan kontrol. Hasil analisis Anova menunjukan bahwa nilai signifikasi atau $\mathrm{P}$-value lebih kecil dari pada 0,05 $(\mathrm{P}<0,05)$ sehingga berarti bahwa perlakuan berbeda nyata atau memberikan pengaruh yang signifikan. Artinya perlakuan memberikan respon yang berbeda terhadap serangan hama dan efektifitas baik pestisida pada ubi jalar. 
Prosiding Seminar Nasional Pembangunan dan Pendidikan Vokasi Pertanian

Politeknik Pembangunan Pertanian Manokwari, 31 Juli 2021

e ISSN : 2774-1982

DOI : https://doi.org/10.47687/snppvp.v2i1.195

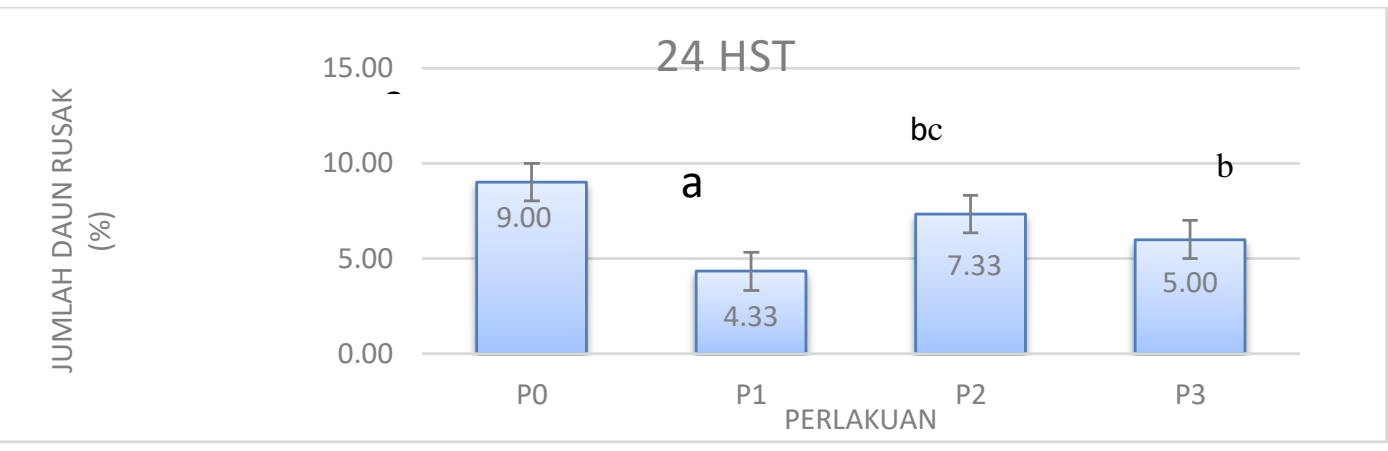

Gambar 2. Jumlah Daun Rusak pada 24 HST

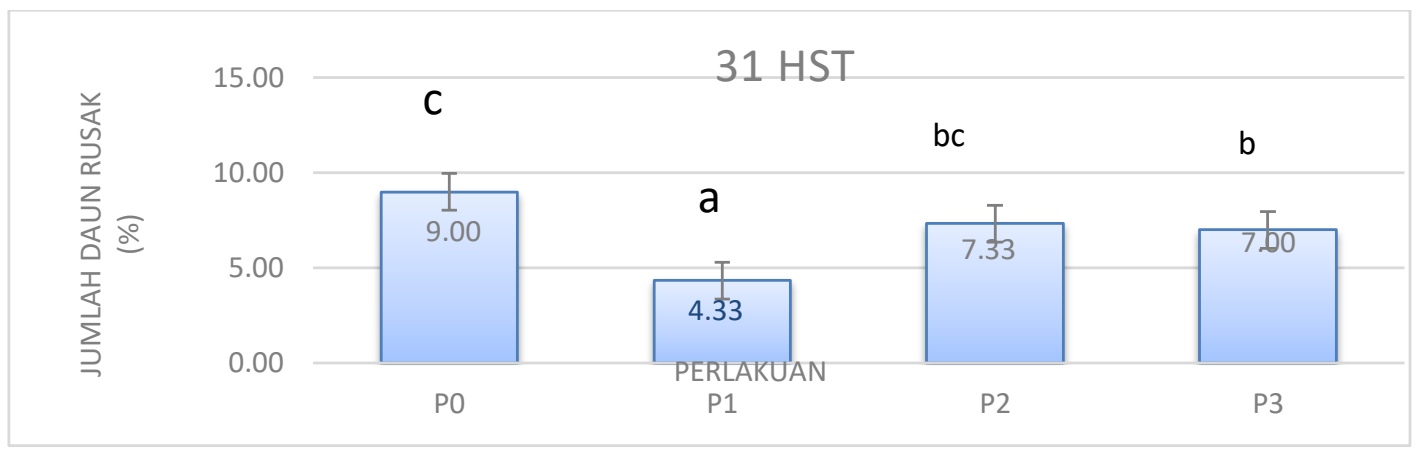

Gambar 3. Jumlah Daun Rusak pada 31 HST

Gambar 3. memperlihatkan bahwa perlakuan P0 (ekstrak 1, kontrol tanpa perlakuan) memberikan respon daun rusak dengan rata-rata (9.00\%), perlakuan P1 (ekstrak 2, ekstrak sirih hutan:tembakau 1:1) dengan serangan rata-rata (4,33\%), perlakuan P2 (ekstrak sirih hutan : tembakau) dengan rata-rata $(7,67 \%)$, dan perlakuan P3 (ekstrak sirih hutan : tembakau) dengan rata-rata (7\%). Secara deskriptif dapat dilihat bahwa perlakuan P1 memiiki rata-rata daun rusak terserang hama lebih kecil dibandingkan perlakuan P2, P3 dan perlakuan kontrol. Hasil analisis Anova menunjukan bahwa nilai signifikasi atau Pvalue lebih kecil dari pada $0,05(\mathrm{P}<0,05)$ sehingga berarti bahwa perlakuan berbeda nyata atau memberikan pengaruh yang signifikan. Artinya perlakuan memberikan respon yang berbeda terhadap serangan hama pada daun ubi jalar. 
Prosiding Seminar Nasional Pembangunan dan Pendidikan Vokasi Pertanian

Politeknik Pembangunan Pertanian Manokwari, 31 Juli 2021

e ISSN : 2774-1982

DOI : https://doi.org/10.47687/snppvp.v2i1.195

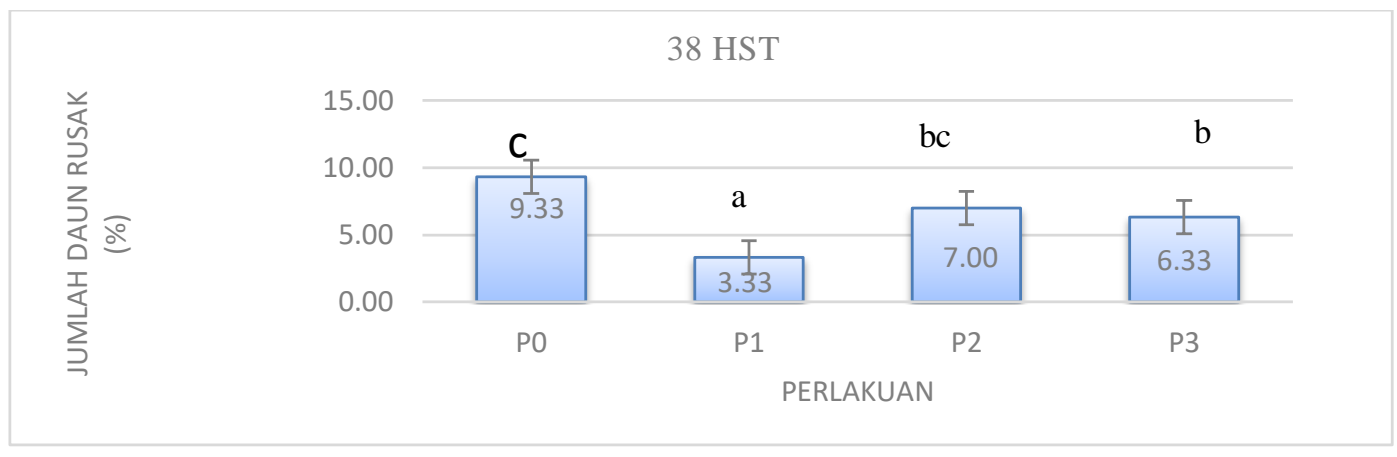

Gambar 4. Jumlah Daun Rusak pada 38 HST

Gambar 4. memperlihatkan bahwa perlakuan P0 (ekstrak 1, kontrol tanpa perlakuan) memberikan respon daun rusak dengan rata-rata (9.33\%), perlakuan P1 (ekstrak 2, ekstrak sirih hutan:tembakau 1:1) dengan rata-rata (3.33\%), perlakuan P2 dengan ratarata $(7.67 \%)$, dan perlakuan P3 (ekstrak sirih hutan : tembakau) dengan rata-rata (7\%). Secara deskriptif dapat dilihat bahwa perlakuan P1 memiiki rata-rata daun rusak terserang hama lebih kecil dibandingkan perlakuan P2, P3 dan perlakuan kontrol. Hasil analisis Anova menunjukan bahwa nilai signifikasi atau $\mathrm{P}$-value lebih kecil dari pada $0,05(\mathrm{P}<0,05)$ sehingga berarti bahwa perlakuan berbeda nyata atau memberikan pengaruh yang signifikan. Artinya perlakuan memberikan respon yang berbeda terhadap serangan hama pada daun ubi jalar.

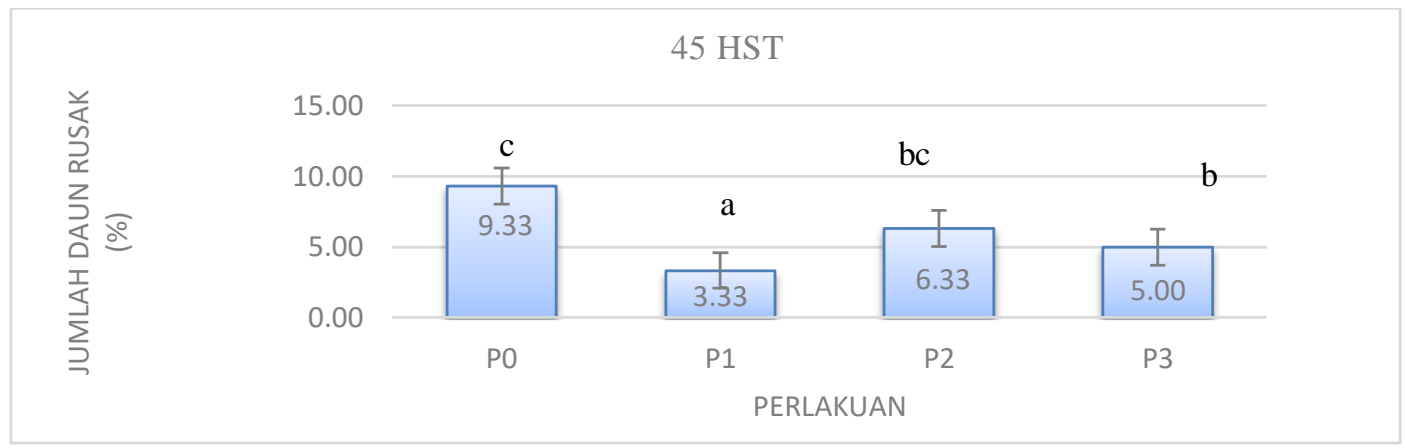

Gambar 5. Jumlah Daun Rusak pada 45 HST

Gambar 5 memperlihatkan bahwa perlakuan P0 (ekstrak 1, kontrol tanpa perlakuan) memberikan respon daun rusak dengan rata-rata (9,33\%), perlakuan P1 (ekstrak 2, ekstrak sirih hutan: tembakau 1:1) dengan rata-rata (3,33\%), perlakuan P2 (ekstrak sirih hutan: tembakau) dengan rata-rata $(6,33 \%)$, dan perlakuan P3 (ekstrak sirih hutan: tembakau) dengan rata-rata $(6,33 \%)$. Secara deskriptif dapat dilihat bahwa perlakuan P1 memiiki rata-rata daun rusak terserang hama lebih kecil dibandingkan perlakuan P2, P3 
Prosiding Seminar Nasional Pembangunan dan Pendidikan Vokasi Pertanian

Politeknik Pembangunan Pertanian Manokwari, 31 Juli 2021

e ISSN : 2774-1982

DOI : https://doi.org/10.47687/snppvp.v2i1.195

dan perlakuan kontrol. Hasil analisis Anova menunjukan bahwa nilai signifikasi atau Pvalue lebih kecil dari pada $0,05(\mathrm{P}<0,05)$ sehingga berarti bahwa perlakuan berbeda nyata atau memberikan pengaruh yang signifikan. Artinya perlakuan memberikan respon yang berbeda terhadap serangan hama pada daun ubi jalar.

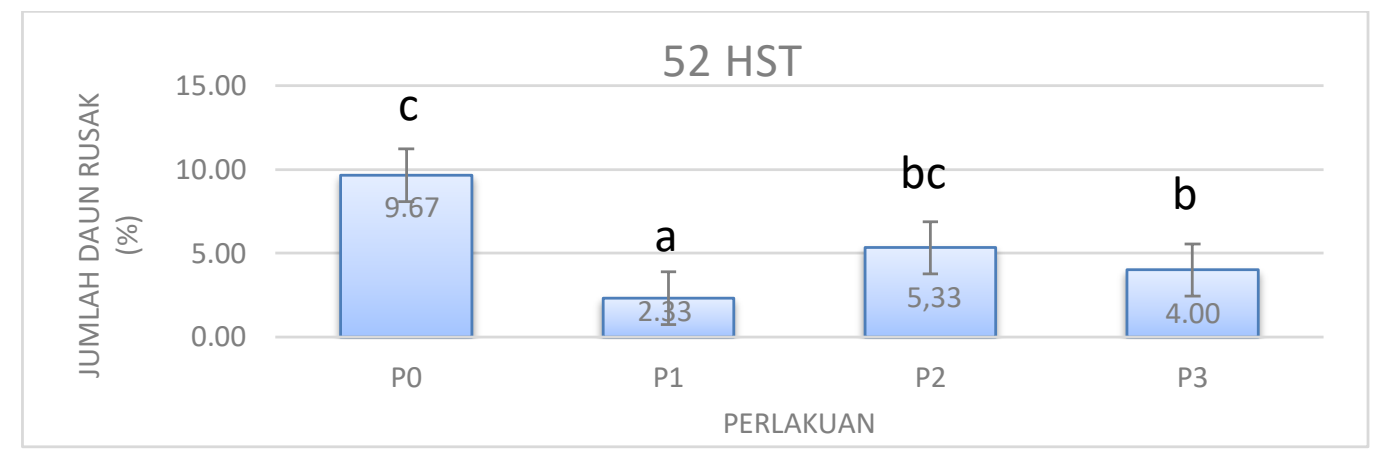

Gambar 6. Jumlah Daun Rusak pada 52 HST

Gambar 6 memperlihatkan bahwa perlakuan P0 (ekstrak 1, kontrol tanpa perlakuan) memberikan respon daun rusak dengan rata-rata $(9,67 \%)$, perlakuan P1 (ekstrak 2, ekstrak sirih hutan: tembakau 1:1) dengan rata-rata (2,33\%), perlakuan P2 (ekstrak sirih hutan: tembakau) dengan rata-rata $(5,33 \%)$, dan perlakuan P3 dengan rata-rata (4\%). Secara deskriptif dapat dilihat bahwa perlakuan P1 memiiki rata-rata daun rusak terserang hama lebih kecil yaitu (2,33\%) dibandingkan perlakuan P2, P3 dan perlakuan kontrol. Hasil analisis Anova menunjukan bahwa nilai signifikasi atau P-value lebih kecil dari pada 0,05 $(\mathrm{P}<0,05)$ sehingga berarti bahwa perlakuan berbeda nyata atau memberikan pengaruh yang signifikan. Artinya perlakuan memberikan respon yang berbeda terhadap serangan hama pada daun ubi jalar.

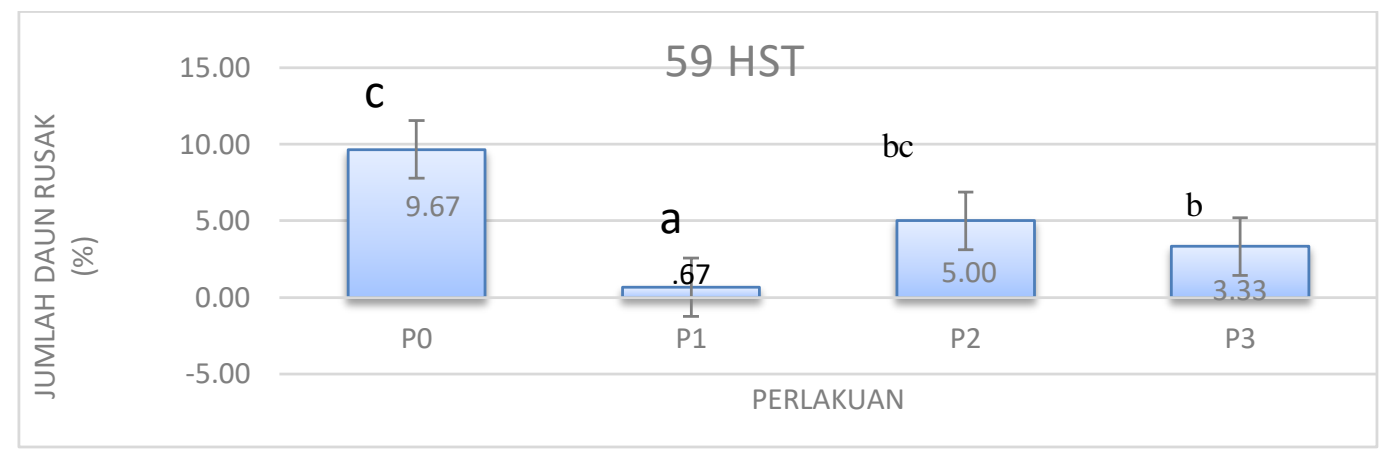

Gambar 7. Jumlah Daun Rusak pada 59 HST 
Prosiding Seminar Nasional Pembangunan dan Pendidikan Vokasi Pertanian

Politeknik Pembangunan Pertanian Manokwari, 31 Juli 2021

e ISSN : 2774-1982

DOI : https://doi.org/10.47687/snppvp.v2i1.195

Gambar 7 memperlihatkan bahwa perlakuan P0 (ekstrak 1, kontrol tanpa perlakuan) memberikan respon daun rusak dengan rata-rata $(9,67 \%)$, perlakuan P1 (ekstrak 2, ekstrak sirih hutan: tembakau 1:1) dengan rata-rata (0,67\%), perlakuan P2 (ekstrak sirih hutan: tembakau) dengan rata-rata (5\%), dan perlakuan P3 dengan rata-rata $(3,33 \%)$. Secara deskriptif dapat dilihat bahwa perlakuan P1 memiiki rata-rata daun rusak terserang hama lebih kecil dibandingkan perlakuan P2, P3 dan perlakuan kontrol. Hasil analisis Anova menunjukan bahwa nilai signifikasi atau $\mathrm{P}$-value lebih kecil dari pada $0,05(\mathrm{P}<0,05)$ sehingga berarti bahwa perlakuan berbeda nyata atau memberikan pengaruh yang signifikan. Artinya perlakuan memberikan respon yang berbeda terhadap serangan hama pada daun ubi jalar.

Dengan uji beda nyata maka hasil pada kajian yang telah digunakan untuk menampilkan hasil yang digunakan sebagai bahan materi penyuluhan yaitu pada sampel perlakuan 1 ekstrak 2, (sirih hutan: tembakau, 1:1 atau $500 \mathrm{ml}: 500 \mathrm{ml}$ ) dengan perbandingan bahan $1000 \mathrm{mg}$, sirih hutan dengan $250 \mathrm{mg}$ tembakau. Tingkat kelebihan bahan yaitu pada pestisida nabati ekstrak sirih hutan yang digunakan sebagai bahan pestisida nabati cair pada pengendalian hama tanaman ubi jalar (Ipomea batatas L.).

Daun sirih hutan mengandung fenol dan kookol, efektif untuk mengendalikan hama tunggau, thrips, dan kutu penghisap. Kegunaan daun sirih yang perlu diketahui / sirih merupakan tanaman yang tingginya mencapai $15 \mathrm{~m}$. daun berbentuk jantung, jika diremas mempunyai aroma sedap, bagian tanaman yang digunakan adalah daunnya. Daun sirih mengandung minyak astiri sebanyak 4\% (hidroksi kavikol, kavikol, kavibetol, estragol, eugenol, metil eugenol, karvakrol, terpen, dan seskuiterpen) tannin, diastae, gula, dan pati. Kandungan minyak astirinya memiliki daya membunuh kuman (bakterosid), fungi dan jamur (Maharina et al., 2013; Suhartini et al., 2017; Siamtuti et al., 2017).

\section{KESIMPULAN}

Hasil penelitian menunjukkan bahwa hasil pestisida ekstrak sirih hutan dan tembakau berpengaruh signifikan terhadap intensitas serangan hama. Hasil terbaik pada perbandingan ekstrak sirih hutan dan tembakau $1: 1$ yang ditunjukkan dengan jumlah daun ubi jalar yang rusak paling sedikit.

\section{DAFTAR PUSTAKA}

Elwin \& Mual, C.D. (2020). Pengaruh Pestisida Nabati Jeruk Nipis berbasis Mikroorganisme Lokal (MOL) terhadap Serangan Hama (Grayak, Belalang, Boleng) 
Prosiding Seminar Nasional Pembangunan dan Pendidikan Vokasi Pertanian

Politeknik Pembangunan Pertanian Manokwari, 31 Juli 2021

e ISSN : 2774-1982

DOI : https://doi.org/10.47687/snppvp.v2i1.195

dan Bobot Umbi Tanaman Ubi Jalar (Ipomoea batatas L. Lam), Jurnal Triton, 11(1), 7-15.

Maghfirillah, G. M., Anwarudin, O., \& Nazaruddin, N. (2020). Perilaku Petani Padi dalam Mengimplementasikan Pengendalian Hama Terpadu (PHT) Menggunakan Tanaman Refugia, Jurnal Inovasi Penelitian, 1(3), 623-632.

Maharina, K. E., Aini, L. Q., \& Wardiyati, T. (2013). Aplikasi Agens Hayati dan Bahan Nabati Sebagai Pengendalian Layu Bakteri (Ralstonia solanacearum) pada Budidaya Tanaman Tomat. Jurnal Produksi Tanaman, 1(8).

Saputra C. Anwarudin O. \& Sulistyowati D. (2018). Persepsi dan adopsi pengendalian hama terpadu lalat buah pada tanaman mangga di Kecamatan Greged Kabupaten Cirebon Provinsi Jawa Barat, Jurnal Penyuluhan Pertanian, 13(2), 46-60.

Siamtuti, W. S., Aftiarani, R., Wardhani, Z. K., Alfianto, N., \& Hartoko, I.V. (2017). Potensi Daun Sirih (Piper betle, L) Dalam Pembuatan Insektisida Nabati yang Ramah Lingkungan. Prosiding SNPBS (Seminar Nasional Pendidikan Biologi dan Saintek) ke-2, 23 Agustus 2017.

Suhartini, S., Suryadarma, P., \& Budiwati, B. (2017). Pemanfaatan Pestisida Nabati pada Pengendalian Hama Plutella Xylostella Tanaman Sawi (Brassica juncea L.) Menuju Pertanian Ramah Lingkungan, Jurnal Sains Dasar, 6(1), 36-43.

Tahyudin, T., Anwarudin, O., \& Hartono, R. (2020). Perilaku petani dalam mereduksi penggunaan pestisida kimia pada budidaya bawang merah, Jurnal Kommunity Online, 9(1), 211-30. 